\title{
Network governance in action: the case of Groningen complex decision-making in urban regeneration
}

\author{
Gerard van Bortel
}

Received: 4 September 2008/Accepted: 4 December 2008/Published online: 18 March 2009

(C) The Author(s) 2009. This article is published with open access at Springerlink.com

\begin{abstract}
Theories on network governance constitute a promising approach to a better understanding of complex decision-making and problem-solving. Network theories are increasingly used in housing research. In this paper we present case-study findings on urban regeneration decision-making in Groningen, a medium-sized city in the North of the Netherlands. We used a network governance approach as an analytical framework. Social landlords and local government in Groningen have been collaborating in urban regeneration processes for many years. In 2006 negotiations between these actors on a renewal of the Local Urban Regeneration Covenant ran into difficulties and encountered seemingly insurmountable differences of opinion. These difficulties were largely caused by the increased complexity of the decision-making process, the large number of actors involved and a shift in focus from 'bricks-and-mortar' investments to a more balanced approach including social and economic aspects of urban regeneration. In this paper we analyse decision-making on urban regeneration policy in Groningen over the past 10 years. The outcomes of the case study demonstrate the usefulness of the network approach as a framework to analyse decision-making processes. The paper also identifies strategies used by actors in the field to successfully deal with complexities and uncertainties in networks.
\end{abstract}

Keywords Network governance · Urban regeneration · Housing associations · Groningen

G. van Bortel $(\bowtie)$

OTB Research Institute for Housing, Urban and Mobility Studies, Delft University of Technology,

Delft, The Netherlands

e-mail: g.a.vanbortel@tudelft.nl

URL: http:॥www.otb.tudelft.nl 


\section{Introduction}

\subsection{Understanding and influencing complex regeneration decision-making}

Urban renewal policies are generally laid down in area action plans, master plans or covenants. The development of these plans involves many government, market, third-sector and community actors. Due to its complexity these decision-making processes often end up in deadlock or exclude weak actors like residents (Swyngedouw 2005). Network governance theorists have developed frameworks that claim to increase our understanding of these processes and provide instruments to cope with the complexity of contemporary public-sector decision-making (Koppenjan and Klijn 2004). In this article we put the network governance framework to the test by analysing resent urban regeneration decision-making processes in Groningen (The Netherlands) concerning the renewal of the Local Urban Regeneration Covenant.

In Sect. 2 we introduce the network governance approach and discuss important characteristics of networks such as pluriformity, closedness, interdependency and dynamics. We investigate the uncertainties connected with problem-solving and decisionmaking in complex networks and offer possible solutions for handling complexity and uncertainty. We continue in Sect. 3 with a summary of shifts in governance in urban renewal and affordable housing provision. Starting on a European level, we subsequently summarize the institutional context of the social housing sector in the Netherlands and continue by describing the urban renewal network in Groningen. In Sect. 4 the decisionmaking dynamics in Groningen are analysed using network governance concepts. We conclude this paper by discussing the usefulness of the network approach as an analytical framework and as a toolbox to be used by practitioners in the field.

\subsection{Research design}

This article presents preliminary results from an ongoing doctoral research project that explores the shifts in housing governance and will focus on the role and position of social landlords in urban decision-making processes in England and the Netherlands. Data for this article was gathered by conducting 25 interviews with key informants from housing associations and the Groningen local authority. The interviews were conducted by the author in collaboration with two City Council officials in preparation of a policy conference to renew the local area agreement, the Local Urban Renewal Covenant.

The interviewees included three aldermen as well as the development, planning and finance managers from the housing associations that were involved in urban renewal and their counterparts within the Groningen City Council. The interviews were structured around three types of network uncertainty as identified by Koppenjan and Klijn (2004), i.e. substantive, strategic and institutional uncertainties. We will discuss these uncertainties in greater detail in Sect. 2.4. The following topics were raised during the interviews:

1. Strategies and ambitions of the own organization;

2. Evaluation of past decision-making processes;

3. Possible efficiency gains in 'bricks-and-mortar' investments;

4. Social investments issues;

5. The coordination and management of urban regeneration interventions.

In addition to interview data, the findings presented in this paper are based on desk research involving policy documents and meeting notes and the participant observation of a high-level policy conference. 
The interviewees did not include any residents' representatives because the latter did not participate in the policy conference that constitutes an important focal point in this article. In a later phase however, residents were involved in public consultation on the results of the negotiations between the City Council and the housing associations.

The author had exceptional access to urban renewal decision-making in Groningen. This was because of his 8 years of experience as a practitioner working for a housing association in Groningen from 1996 to 2004 and in 2006 as an external facilitator at a crucial stage in decision-making concerning the renewal of the Local Urban Renewal Covenant. The danger of researcher bias due to this intimate connection with actors in the Groningen urban renewal network is limited, however. This researcher has no formal connections with actors in Groningen and no stake in the outcomes of decision-making processes. In addition we will use other independent external assessments of urban renewal decisionmaking in Groningen and the level of resident participation in the concluding section of this article (Van Hulst et al. 2008; Van de Wijdeven and De Graaf 2008).

\section{Understanding governance networks}

\subsection{Network theory}

In this paper we use a network governance approach to increase our understanding of complex decision-making in Groningen. Mullins and Rhodes (2007) identify several strands of network/systems theory in the field of housing research. They distinguished the following key strands of network concepts: (1) policy networks (2) network governance (3) supply networks/chains (4) organizational fields and (5) complex systems. Mullins and Rhodes synthesized these strands of network analysis into five overarching themes and interests:

1. a common emphasis on the way in which relationships between organizations affect the behaviour of individual organizations;

2. a recognition that the shape and structure of the network in which organizations operate can have significant implications for decision-making;

3. an interest in the way in which policy interventions are and should be structured in governance networks;

4. a shared interest in the way in which organizations adapt to changes in their environment and seek to influence these changes;

5. an interest in the boundaries of networks and the different levels of decision-making that influence what happens in networks.

We have chosen to use the network governance strand to increase our understanding of decision-making processes because this approach specifically targets the relations between interdependent actors and the interactions that result from decision-making processes in situations where there is no dominant actor (see De Bruijn et al. 2002; Kickert et al. 1997; Klijn et al. 1995; Koppenjan and Klijn 2004; Klijn and Koppenjan 2007; Sørensen and Torfing 2007).

\subsection{How governance networks work}

The process of network formation is driven by interdependencies that induce actors to negotiate with others to attain the resources needed to achieve their goals. Their 
interactions lead to the formation of rules that are sustained by and changed through these interactions (Koppenjan and Klijn 2004). These interactions create relationship patterns that over time acquire more robustness. Relationship patterns create formal and informal rules for future interactions. And it is these rules and patterns of interaction that constitute a 'network'.

Koppenjan and Klijn describe series of interactions as 'policy games'. The actors' resources and their strategic behaviour determine their position in the network. Actors do not select strategies at random but are guided by their own objectives and perceptions, their own stakes in the outcome and the strategies of other participants. Policy games take place in activated parts of a network called 'arenas'. A game may consist of multiple arenas and game rounds. Each round is concluded by a crucial decision or event, for example the signing of a covenant or-in a less positive sense - a major conflict. The developments and outcomes of decision-making are influenced by the strategies the actors use. These strategies can lead to breakthroughs but also to blockages and deadlocks in the decision-making process.

\subsection{Characteristics of complex networks}

De Bruijn et al. (2002) identify four characteristics of networks that have a major influence on the level of complexity and the nature of decision-making processes. We will give a short overview of these characteristics and illustrate them with examples from the Groningen case. The four characteristics are:
(a) Pluriformity;
(b) Closedness;
(c) Interdependency;
(d) Dynamics.

\subsubsection{Pluriformity}

The level of pluriformity is reflected in the number of actors involved in the governance network and their organizational characteristics. Furthermore, pluriformity is influenced by the variety of goals and perceptions of network actors. In Groningen the number of social landlords involved in urban renewal projects is limited. Due to mergers this number decreased from nine in the 1980s to only five in 2008. In addition, few local authority departments are involved in the bricks-and-mortar urban renewal, and Groningen has no devolved municipal structure. In comparison, Amsterdam has 14 housing associations and five borough authorities with devolved housing policy responsibilities. However, as we will discuss later in this paper, the number of actors involved in urban renewal decisionmaking in Groningen has increased considerably due to the inclusion of more social objectives in urban regeneration policy.

Groningen has a long tradition (since the 1970s) in developing mutual urban renewal goals. These have been formalized in local area agreements between housing associations and the local authority, thereby limiting the level of pluriformity in goals and perceptions. In addition social landlords and the Groningen City Council are used to jointly commissioning housing market research. They have established an organizational structure to coordinate urban renewal decision-making and implementation, thereby further decreasing pluriformity. 


\subsubsection{Interdependency}

Interdependencies in a network originate from the fragmentation of resources among actors. Actors need these resources to attain their own goals. Therefore they often need to collaborate with other actors. The resources range from financial grants, loans, building locations, building permits and public endorsement of plans to democratic anchorage by the city council. For example, housing associations in the Netherlands are often strongly dependent upon local authorities to provide building locations. Municipalities, on the other hand, need social landlords as delivery vehicles for new affordable homes and urban regeneration. This is especially the case for the development of new affordable housing, as each municipality has a limited number of housing associations active in its territory.

An additional form of interdependency was introduced in Groningen by the recent shift from bricks-and-mortar investments towards an approach balancing the social and physical investments. This resulted in an increased emphasis on initiatives aimed at social targets like crime prevention, supporting multi-problem families, creating opportunities for the long-term unemployed and tackling the school dropout problem.

\subsubsection{Closedness}

A third element of complex decision-making is closedness. Actors in a network are not automatically sensitive to external steering interventions by the state or other government agencies. National and local governments are no longer dominant actors that can coerce other actors to implement government policy. This is illustrated by the inability of the Dutch housing minister in the 1990s to increase the number of social rental homes being sold. The central government's goal was ignored by most housing associations (Van Bortel and Elsinga 2007).

De Bruijn et al. (2002) argue that organizations need a certain degree of closedness, because receptiveness to all external signals would send them adrift without a fixed aim or objective. Closedness enables organizations to retain their focus and incorporate only a limited amount of the complexity and environmental turbulence into their activities. Closedness is often the result of the power and autonomy of the actor(s) involved. Autonomous actors do not usually need the resources offered by other actors and can subsequently simply ignore their initiatives.

Closedness can also be found in Groningen. It is known that actors (housing associations and local authorities) are used to working towards mutually supported urban renewal policies and that they jointly commission housing market research. However, the interviews with municipal representatives suggest that housing associations were not really inclined to listen to the local government's plea to financially support social investments until they identified this as a source of leverage to advocate their wish for more efficient project development procedures.

The difficulty of accessing decision-making arenas is another form of closedness that was very prominent in Groningen. Local authorities and housing associations worked very closely together in the development of an urban regeneration strategy. Important decisions were discussed and agreed upon before they involved other actors. De Kam (2004) argues that the intensive relations between the local authority and housing associations resulted in formidable entry barriers for outsiders like commercial real estate developers or non-local housing associations. Entry of outsiders could be interpreted as a sign that local actors were not able to solve the problems on their own. However, this closedness was not limited to outsiders. The close collaboration between city administrators and social landlords also 
made it difficult for citizens to influence urban renewal policy (De Kam 2004). In addition Edelenbos (2004) concluded that there was little attention for the role and position of elected council members in the political debate on urban renewal policy. To summarize, the role of the professionals was very dominant.

\subsubsection{Dynamics}

Networks are constantly in transition due to changes in the closedness, interdependency and pluriformity of actors in the network and due to contextual developments. The network landscape changes, some actors leave, others join in, rules can change and so can the distribution of resources. This means that opportunities and barriers for successfully influencing decision-making can change over time. Decision-making in networks is therefore often unpredictable. Due to the absence of a hierarchical structure, every actor can try to influence the agenda-setting and decision-making process. In a complex network this is not an easy process. Fragmented interdependencies can make it necessary to interact with many different actors to influence outcomes. Furthermore in complex networks there are often no 'done deals'. New actors in the network, new decision-making rounds or altered network characteristics can lead to the re-evaluation of decisions made in the past, with possibly different outcomes.

The concept of network dynamics can be illustrated by the shift from the bricks-andmortar approach in Groningen towards a process balancing social and economic investments. Due to this shift many new actors from the social sector joined in the decision-making game. We can illustrate this by applying Koppenjan and Klijn's (2004) network concepts to the Groningen case. Figure 1 shows two decision-making games. The first policy game addresses the bricks-and-mortar pillar of urban regeneration. The second game depicted in Fig. 1 is concerned with social investments. Social investments are not new, but investments in health, education, crime prevention and unemployment programmes have only recently been seen as important elements in urban regeneration in the Netherlands (VROM 2007). This new vision has resulted in the interconnecting of both decision-making games.

As can be seen in Fig. 1, a new policy arena has emerged connecting the bricks-andmortar and the social investments games. Both games take place in different networks with dissimilar rules, values and vocabulary. These differences can (and did) cause problems and sometimes irritation. For example, informants from the bricks-and-mortar network mention the lack of neighbourhood orientation among the actors involved in social investments as a problem. Actors from the social investments network are blamed for rarely participating in urban regeneration meetings and activities on a neighbourhood level. Another point of criticism levelled at actors from the social investments network is their singular focus on long-term programmes and specific target groups, like immigrant women or school dropouts. Actors from the bricks-and-mortar network appear to prefer a more geographically demarcated and short-term approach.

Adapted from Koppenjan and Klijn 2004. Comments on bricks-and-mortar and social investments added by author.

\subsection{Uncertainties in networks}

After discussing the characteristics of complex networks described by De Bruijn et al. (2002), we shall delve deeper into the network approach as a useful tool for getting a better understanding of complex decision-making processes. An important factor influencing these processes is uncertainty. Decision-making in complex networks has to deal with several forms of uncertainty (Koppenjan and Klijn 2004): 


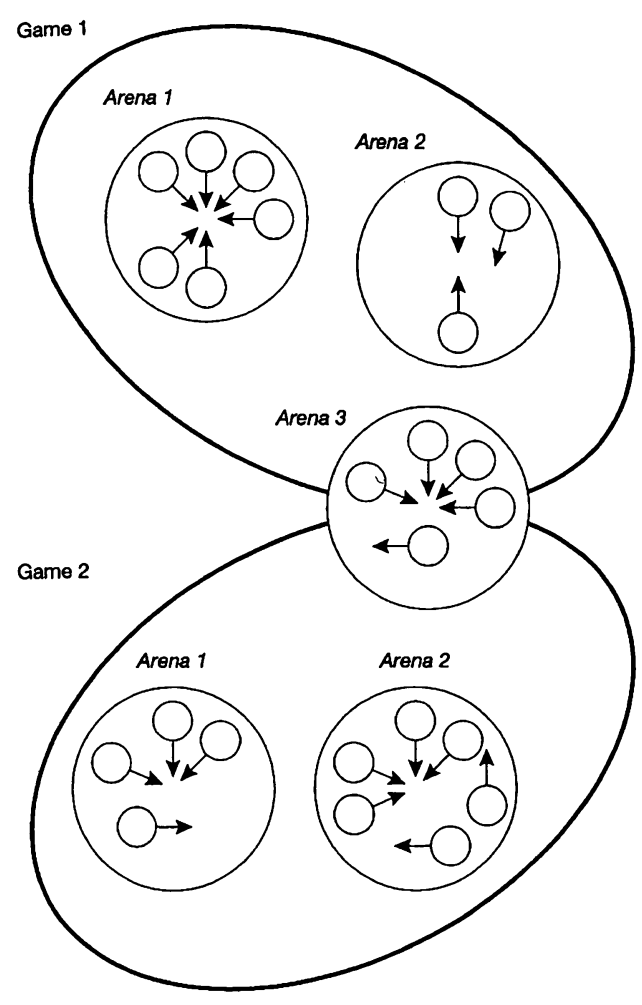

Bricks-and-mortar investments

\section{Social investments}

Fig. 1 Connection between the 'bricks-and-mortar' and 'social investments' games. Adapted from Koppenjan and Klijn 2004. Comments on bricks-and-mortar and social investments added by author

- Substantive uncertainty;

- Strategic uncertainty;

- Institutional uncertainty.

We will illustrate how these uncertainties played out in Groningen. As we discussed earlier in this paper, the aim of the Groningen City Council to seek additional funding for social investments connected very well with the wish of housing associations to organize the development of new homes in urban renewal areas more efficiently. By connecting both objectives, both actors wanted to 'increase the size of the pie' by reinvesting project development efficiency gains in the social projects. This initiative, however, created new substantive, strategic and institutional uncertainties.

\subsubsection{Substantive uncertainty}

Substantive uncertainty is connected with the lack of shared knowledge about the nature of complex problems and viable solutions. Actors can have different problem perceptions and dissimilar frames of reference because they can interpret available information very differently. Adding more information is not always a solution because it can increase, instead of diminish, substantive uncertainty. New information brought forward by one actor is often debated or simply ignored by other actors. In Groningen actors have a long tradition 
in jointly commissioning research in housing market developments. This situation can limit substantive uncertainty because knowledge is based on a shared frame of reference.

\subsubsection{Strategic uncertainty}

Actors involved in decision-making can have different objectives. They may base their actions on perceptions of reality that are not acknowledged or are unknown to other participants. This increases the strategic uncertainty. Furthermore, actors respond to and anticipate each other's strategic moves. Altogether, this can lead to large variety of strategies and a high level of unpredictability in the decision-making process, thereby creating strategic uncertainties.

In Groningen strategic uncertainties arose from the mix of physical and social urban regeneration investments. This mix was new and created uncertainties about the different responsibilities of the actors involved. Strategic uncertainty was further increased by the intention of housing associations to not only financially contribute to social investments but also to control and monitor these investments. Many City Council officials regarded the social investments as their prerogative, even if these investments were partly funded by housing associations.

\subsubsection{Institutional uncertainty}

Complex decision-making often involves large numbers of actors. These actors frequently come from different institutional backgrounds, bringing with them their own culture and values. Complex problems often cut across existing organizational and institutional boundaries, administrative levels and networks. Interaction in policy games and the outcomes of these games are therefore influenced by different and sometimes conflicting rules, vocabulary/jargon and values. Actors often trust each other, but interactions can also be guided by high levels of distrust.

One of the reasons for institutional uncertainty in Groningen arose from the differing opinions about the way efficiency gains from urban renewal projects should be allocated to social investments. Should there be a central 'till' from which all social projects should be funded? And if so, who should control this till? Most City Council officials preferred this idea, whereby the local authority would be managing the till. Housing associations supported an option whereby funds would flow directly from the social landlord into the social investment projects.

The three forms of uncertainty distinguished in the Groningen case are interconnected. The institutional uncertainty about the way efficiency gains should be allocated to social investments was strongly influenced by the strategic uncertainty about the responsibilities of housing association and the Groningen City Council.

\section{Developments in social housing governance}

\subsection{European developments}

Throughout Europe, central governments are increasingly withdrawing from social housing provision. They are shifting tasks and responsibilities to lower levels of government or non-governmental organizations (UNECE 2006; Whitehead and Scanlon 2007). There is 
an overall trend towards devolution, decentralization and privatization. This trend was partly triggered by beliefs prevailing in the eighties concerning the role of the state in housing provision. In most countries this resulted in a reduction in public housing expenditure. In general, housing became more market-oriented, competitive and open to economic pressures (Priemus et al. 1993; Priemus 2004). Overall, the central government is still an important party in housing systems, but a shift in orientation can be seen from a 'providing state' to an 'enabling state' (Doherty 2004, p. 256). These developments have changed the decision-making processes; the overall trend is towards an increasing number of actors and a fragmentation of power and resources. These developments are not natural phenomena. They are caused by the economic, social and political developments that triggered changes in public administration, like the rise of New Public Management approaches (Osborne and Gaebler 1992).

In addition to this, in many European countries other developments can be identified. There is a trend for housing associations to bring their physical and spatial investments (the traditional bricks-and-mortar approach) more in balance with the economic and social aspects of urban renewal. This is illustrated by the iN Business for Neighbourhoods initiative by housing associations in England and the 'Answer to Society' by the Dutch housing associations in 2007 (Aedes 2007). In both countries, housing associations commit themselves to invest in local communities.

Furthermore, an increased emphasis is put on resident empowerment, participative decision-making and public accountability. This is illustrated in England by the 'Every tenant matters' review (Cave 2007) and the subsequent 'tenant-based' reform of the regulation of housing associations. In the Netherlands the 'Confidence in the Neighbourhood' report published by the Dutch Scientific Council for Government Policy (WRR 2005) triggered a trend towards more resident involvement in urban renewal. The city of Groningen is one of four local authorities forming a front-runner group of municipalities that want to give residents a central position in urban renewal decision-making based on the 'Confidence in the Neighbourhood' philosophy.

\subsection{Developments in the Netherlands}

\subsubsection{The Dutch social housing sector in an international perspective}

In many European countries governments are decreasing state funding and state involvement in the provision of social housing and giving a greater role to private and third-sector organizations. Developments in the Netherlands are no exception, although in some respects the Dutch case is unique. The Dutch social rented sector covers $35 \%$ of the total housing stock. This substantial market share is remarkable in an international perspective, as the UK takes second place with $20 \%$ of the stock. In most European countries the social rented sector accounts for less than $10 \%$ of the housing stock (Whitehead and Scanlon 2007).

The (almost non-existent) financial relationship between the government and social landlords is another remarkable feature of the Dutch housing system. In most countries social housing associations can still count on government subsidies for the construction of housing (Whitehead and Scanlon 2007). The Netherlands is the only country that has almost totally abolished subsidies in the social rented sector. In an extensive 'grossing and balancing operation' during the 1990s, all outstanding government loans to housing associations were netted against supply-side housing subsidy obligations of the Dutch state. 


\subsubsection{From independence to semi-government organizations and back again}

The social housing sector in the Netherlands has undergone numerous changes since it first came into being around 1860 and since the introduction of the Housing Act in 1901. Housing associations were private organizations that were subject to varying degrees of government influence during the twentieth century. After World War II the social housing sector became a crucial instrument in the battle against housing shortages. From 1945 until 1990, the Dutch government remained closely involved in the operations and funding of housing associations. As a result housing associations gradually turned into semi-public institutions that had strong hierarchical ties with the government. The grossing and balancing operation fundamentally changed the relations between government and Dutch housing associations, giving the latter a virtually autonomous position.

Though fully independent financially and administratively since the $1990 \mathrm{~s}$, housing associations in the Netherlands still require authorization for high-impact decisions. Under the terms of the Housing Act their responsibilities and operating conditions are laid down in the Social Rented Sector Management Order (abbreviated BBSH in Dutch). The BBSH stipulates that housing associations are responsible for providing good, affordable housing for people who are unable to pay market prices. The BBSH is not very specific about the results expected from housing associations, and it leaves this point to be negotiated between local authorities and housing associations (Van Bortel and Elsinga 2007).

\subsection{Developments in Groningen}

To understand the interactions between parties in the urban renewal network of Groningen it is essential to get some grasp of the rather atypical nature of this city. Groningen is located in the extreme North of the Netherlands and in its immediate vicinity there are no other cities of consequence. The local authorities of Groningen adopted the slogan 'Nothing goes above Groningen' to accentuate its Northern location, the assets of the city and the high level of self-confidence shared by its residents. The location of Groningen has some drawbacks, however. The economic situation, although improving in recent years, is less prosperous compared with the Western part of the country; unemployment rates are higher and incomes lower. This situation is reflected in the housing market and housing stock. Compared with the West, buying a house in Groningen is relatively affordable. Waiting lists for social housing are relatively short (but for those in dire need of a home still too long).

The market position of the social housing stock in Groningen is vulnerable, as was illustrated by the high levels of housing voids at the end of the 1990s. This market situation stimulated actors in Groningen earlier than those in other Dutch cities to develop large scale-urban renewal programmes. Actors in Groningen have a long tradition of close collaboration in urban regeneration. Since the 1970s, the local authority, housing associations, residents, police, schools and other organizations have worked closely together to improve housing and living conditions in the city. The grossing and balancing operation in the 1990s was not the start of network governance of urban renewal in Groningen. It did however, give housing associations a more powerful and autonomous position vis-à-vis the local authority. Before this operation the local authority was not inclined to involve housing associations in the strategic decisions about urban renewal policy, like the selection of intervention areas (De Kam 2004). 


\section{Decision-making dynamics in the Groningen urban regeneration network}

In this section we shall describe the process of decision-making on urban regeneration policy in Groningen using the network approach discussed earlier. In Groningen we can broadly distinguish three periods or policy games:

(a) Period 1: 1995-1998;

(b) Period 2: 1998-2005;

(c) Period 3: 2005-2007.

These periods have been distinguished by the author. The demarcation is open to discussion and is not an objective empirical fact. However, each period is marked by an important event such as signing off on a covenant between actors. In the following we will discuss these periods in some detail, especially regarding the more recent developments in the period 2005-2007. At the end of each period, there was a significant increase or decrease in the level of uncertainty. This is in line with Koppenjan and Klijn (2004) notion of 'game rounds' that are most often concluded with breakthroughs or deadlocks.

\subsection{Period 1: 1995-1998}

The period starting in the mid-1990s and lasting until 1998 was characterized in Groningen by deteriorating market conditions, rising vacancies and increasing social problems in several neighbourhoods. Housing market surveys predicted mayor redundancies of apartment blocks. This resulted in a strong feeling among most housing associations and the local authority that urgent action was necessary. Groningen was one of the first cities in the Netherlands where in 1998 housing associations and the municipality agreed on large-scale urban regeneration investments, spanning a period of 12 years. The end of this period is demarcated by the signing of the first Local Urban Renewal Covenant in 1998.

\subsection{Period 2: 1998-2005}

In the period 1998-2005 implementation of the 1998 covenant was at the centre of attention. In this period it became clear that residents did not always share the ambitions of the Groningen housing associations and the local authorities. They did not agree with the large number of redevelopment plans. Residents were particularly opposed to the large proportion of demolish-and-rebuild in the redevelopment plans, because inadequate guarantees were given to residents that affordable houses would be available in their old neighbourhood. New dwellings were mainly intended for middle- and high-income households, while many of the incumbent tenants were dependent on affordable housing. Market developments also proved less gloomy than depicted in housing market surveys conducted at the end of the 1990s. Tensions on the housing market remained and waiting lists were still long for those seeking a new home. It also turned out to be difficult to deliver as many housing demolitions and new-build homes as envisioned in the 1998 Local Urban Renewal Covenant. In 2002 these developments led to a revised Local Urban Renewal Covenant ['Het Lokaal Akkoord'] between housing associations and the municipality. In this new agreement demolition targets were adjusted downwards and the focus shifted from quantitative bricks-and-mortar targets towards more qualitative and integrative objectives. The latter focus placed more emphasis on the built environment and living conditions of residents and less on transformation of the housing stock alone (Van der Wal 2004). This shift towards a more balanced approach to urban regeneration was illustrated by the 
selection of several new 'Social Urban Regeneration Areas' in Groningen. These areas would receive an extensive social programme targeting crime, vandalism and anti-social behaviour and only a small proportion of bricks-and-mortar investments.

The 1998-2005 period is demarcated by the 'Nieuw Cement' [New Mortar] exhibition presenting an overview of urban regeneration results in Groningen from 1998 until 2004. Housing associations and the municipality jointly organized this event. The publication accompanying the exhibition contained several essays written by relative outsiders (De Kam 2004; Edelenbos 2004; Ouwehand 2004) that contained-sometimes critical-reflections on the process and outcomes of urban regeneration in Groningen. Critical comments were made about the lack of genuine involvement of residents and elected politicians.

\subsection{Period 3: 2005-2007}

In 2005 the municipality and housing associations started discussions on renewal of the 2002 Local Urban Regeneration Covenant. The emphasis on social investments made these discussions different from those on the earlier covenants. In 2005 a dormant discontent among professionals on the dominance of housing associations and the municipality was inflamed by the publication 'Confidence in the Neighbourhood' ['Vertrouwen in de buurt'] by the Dutch Scientific Council for Government Policy (abbreviated WWR in Dutch). This publication advocated stronger resident participation in improving the living conditions in neighbourhoods and powerful interventions by local governments and others if neighbourhoods lacked the social fibre to deal with problems themselves. Citizens' empowerment was a central theme in the 'Confidence in the Neighbourhood' report. The report mentions housing associations as organizations with the organizational strength and financial resources to take the lead in neighbourhood renewal operations, including coordinating activities targeting social problems.

In Groningen the 'Confidence in the Neighbourhood' (WRR 2005) report inspired many of the professionals participating in urban regeneration projects to apply a more bottom-up approach. In the spring of 2006 a special conference was held in Groningen to discuss the implications of the report. Pieter Winsemius, lead author of the report and former Minister of Housing and Spatial Planning attended the conference together with more than 100 representatives of housing associations, local authorities, police, schools, residents and welfare organizations. The conference resulted in the formulation of 'Ten golden rules of urban regeneration' (Frenay 2006) (Table 1). These rules turned out to be very influential in subsequent discussions on renewal of the Local Urban Regeneration Covenant.

Table 1 The ten golden rules of urban regeneration in Groningen

1. Develop tailor-made approaches for each neighbourhood

2. Create clear roles and responsibilities

3. Give residents breathing space, do not micro-manage

4. Keep it simple

5. Act more and talk less

6. Interact

7. Celebrate successes

8. Keep pace

9. Have confidence, give confidence

10. Nurture a 'can do' attitude

Source: Frenay 2006 
The wide dissemination of the 'Confidence in the Neighbourhood' philosophy could be interpreted as the success story of a well-written report sponsored by a charismatic political figure. Although not underpinned by research, the success of this report could also be interpreted from a 'governing without government' perspective. In that light, its success could also be the result of a brilliant government strategy aimed at changing the rules of decision-making in urban renewal processes through publishing a report by an independent (but state-funded) scientific council that fits the government agenda.

\subsection{Connecting games for social and bricks-and-mortar investments}

The emphasis on the empowerment of residents coincided with a growing notion within the local administration of Groningen that they were unable to fund the social activities needed to tackle problems in the no less than 14 regeneration neighbourhoods in Groningen. The Groningen City Council calculated the amount needed for these social services and concluded that the available municipal funds were insufficient. Instead of lowering their ambitions the local authority asked the local housing associations for assistance. This illustrates that dependencies are closely linked with the goals and ambitions of actors. The City Council could have chosen to lower its ambitions, resulting in a lower investment cost that matched the municipal budget.

In subsequent negations housing associations and the municipality developed solutions entwining the goals of both parties: making bricks-and-mortar urban regeneration more efficient by reducing the red tape and streamlining planning procedures and then reinvesting these efficiency gains in social activities.

Actors developed a new model for project development: the Relay Race Model (in Dutch 'het estafettemodel'). Actors were confident that the Relay Race Model could shorten the time needed to develop urban renewal projects by $40 \%$ (from 4 years to 2.5 years) by organizing the process in a more effective way. Changes included the clear identification of steps in the process and defining clear responsibilities, timelines and output criteria for each step. The parties were confident that this would lead to substantial cost reductions, on average 7,000€ for each new-built dwelling. Housing associations were prepared to use these efficiency gains to fund social investments. But housing associations also wanted guarantees that these funds were used effectively. Some associations were only prepared to sponsor activities in neighbourhoods where their own housing stock was located. What made decision-making difficult was the combination of two different networks: the bricks-and-mortar network and the network dealing with social investments (see Fig. 1 above).

\subsection{Creating a way out of deadlock}

In the autumn of 2006 negotiations on the New Local Performance Agreement reached a critical phase. At that moment decision-making was in a deadlock due to disagreement between the local authority and housing associations about the way funds from bricks-andmortar projects would be made available for social investments. After 2 years of preparation and negotiations, the renewal of the Local Urban Regeneration Covenant seemed more dead than alive.

From a network perspective, the complexity of the governance network on urban renewal issues had reached a critical level. There were too many actors and issues. As one Groningen City Council informant phrased it, 'there were too many pieces on the chessboard.' In addition the frequent and informal contacts between actors hampered decision- 
making by creating a high level of 'noise', hearsay, confusion, mistrust and miscommunication. Quoting another informant from the Groningen City Council:

Groningen is a small place, people bump into each other all the time; during a football game or in the shopping mall. It's impossible to coordinate or manage these interactions in any way, especially because a lot of talk is going on about the people involved and not on the issues at hand.

The CEOs of the two largest housing associations and the administrator of the municipal department of housing and spatial planning decided on a 'pressure-cooker approach'. This entailed holding a two-day conference at a secluded location bringing together all relevant issues and actors from different hierarchical levels.

In interviews preceding the conference, high-level officials expressed trust in the other parties and emphasized that housing associations and the municipality needed each other. However, informants on lower hierarchical levels articulated less trust and confidence. One housing association's informant stated that:

the local authority needs money from housing associations to fund their social investments ambitions. The city council sees the promise to increase the efficiency of the building production as a possibility to get that money, but the city council is not really committed to implementing measures to increase efficiency and it will never be implemented.

A Groningen city administration official felt that housing associations were making the discussion unnecessarily complicated:

housing associations are clever, they have more money than we think. They have made profits due to investments of the local authority. Their financial contribution to the social investment program is peanuts.

Another finding from the interviews was a deeply felt reservation amongst representatives from both housing associations and several municipal departments about the limited organizational capacity of actors in the social investment network to deliver the necessary results.

Information from the interviews was processed in a discussion paper and a detailed programme for the conference. The setting of the policy conference was kept intentionally informal. It was held at a secluded location with many possibilities for interaction in alternating plenary sessions, subgroups and social activities. An overnight stay was compulsory for all participants. To enhance the 'pressure-cooker' effect, the conference programme was structured in such a way that the results (or lack thereof) had to be presented at the end of conference at a session with the three local aldermen in attendance.

Parallel to the plenary and subgroup meetings a draft policy document was written describing the main points of agreement and disagreement. This draft was discussed with participants and adjusted to include their comments. At the end of the two-day conference a policy document was drafted and agreed upon by all participants. In the weeks following the conference this document was developed into a draft New Urban Regeneration Covenant. Early in 2007 the draft covenant was made public for consultation with residents.

Paramount in the New Urban Regeneration Covenant is the balance between investments in bricks-and-mortar and social activities. The joint responsibility of the local authority and housing associations to secure good living conditions in 
neighbourhoods is firmly anchored in the Covenant, specifying activities like crime prevention, sustainable housing management, social inclusion, welfare, health, education and improving neighbourhood facilities. Over the next 10 years housing associations will deliver 8,000 new dwellings in the city, of which 5,000 will be built in urban renewal areas. In the coming 4 years housing associations and the municipality will each invest ten million euros extra in social activities. The investment by housing associations is based on the assumption that the development time of real estate projects will be reduced by $40 \%$. This is not an ex-ante condition for the investments; the actual efficiency gains will be assessed by ex-post measurements. Although considered in the development process, no sanctions are included in the covenant in case of non-compliance. This arrangement illustrates a certain level of mutual trust in the ability and willingness of actors to deliver results.

\section{Conclusions and further research}

In this paper we have presented the network governance approach and used it to take a closer look at urban regeneration decision-making in Groningen. We saw that policy development in this area can be a fairly complex venture, mainly because of the interdependencies between actors and the dynamics in the network. The shift from a bricks-andmortar approach towards a more balanced approach to urban renewal focusing more on social investments constituted a major change in the urban regeneration network in Groningen.

We also showed that this shift towards a more balanced form of urban regeneration turned an already complex - but still functioning-bricks-and-mortar network into an even more complex and-for some time-dysfunctional network due to the interconnection with the social investments network. The Relay Race Model was developed to deliver the efficiency gains in project development. This instrument alone proved insufficient to bring decisionmaking to a successful closure. A very top-down intervention by key officials was necessary. This intervention resulted in a two-day policy conference that included all relevant issues and actors, though excluding the residents. This created the opportunity to reach agreement on the text of the New Urban Regeneration Covenant and create a mechanism to channel financial resources from project development into social investments.

The research for this article did not include the opinions of residents because they were not directly involved in the renewal of the Urban Regeneration Covenant. Recent publications (Van de Wijdeven and De Graaf 2008; Van Hulst et al. 2008) however, have assessed the involvement of residents in, respectively, the implementation of the new Covenant and resident participation in the development of Neighbourhood Action Plans for two priority neighbourhoods in Groningen (named De Hoogte and Korrewegwijk).

The general strategy described in the New Urban Regeneration Covenant has to be delivered by local teams in the 14 priority neighbourhoods in Groningen. According to the Covenant, residents should ideally participate in these teams, but this is still an exception and largely remains a promise to be fulfilled (Van de Wijdeven and De Graaf, 2008). In addition, the 14 local Neighbourhood Teams take very different approaches, thereby creating new forms of complexity and uncertainties that need to be overcome.

The pledge by professionals to base their actions on the 'Confidence in the Neighbourhood' principles (see Table 1 above) has created high expectations among residents about their influence on developments in the neighbourhood (Van de Wijdeven and De Graaf 2008, p. 26). 
As Van de Wijdeven and De Graaf (2008) conclude in their assessment of the decisionmaking process, while on a neighbourhood level professionals in Groningen operate as an intermediary between elected politicians and citizens, the link between the latter two parties is weak. This is supported by the conclusions of Van Hulst et al. (2008), who state that the development of Neighbourhood Action Plans for De Hoogte and Korrewegwijk was dominated by professionals and that the involvement of residents in the development of the Neighbourhood Action Plans and communication on the outcomes of decisionmaking had been limited. The connections between professionals from housing associations and the municipality appear to be so strong that they tend to exclude to some extent the local politicians and residents.

Applying the network approach to urban regeneration decision-making in Groningen increased our understanding of the complexity and the uncertainties involved in these forms of decision-making. Using the network approach we identified instruments and strategies used by actors to cope with uncertainties and complexity. Actors in Groningen developed these tools without explicit knowledge of network concepts.

It remains a topic for further debate and research if a more deliberate use of a network governance toolbox by practitioners would result in better quality and more efficient decision-making processes.

Acknowledgment The author wants to thank the Groningen City Council and the local housing associations for providing access to documents, meetings and key informants. Without their cooperation this paper could not have been written.

Open Access This article is distributed under the terms of the Creative Commons Attribution Noncommercial License which permits any noncommercial use, distribution, and reproduction in any medium, provided the original author(s) and source are credited.

\section{Referenece}

Aedes, (2007). Antwoord aan de samenleving [Answer to Society]. Hilversum: Aedes.

Arrow, K. J. (1963). Social choice and individual values (2nd ed.). New York: John Wiley.

Cave, M. (2007). Every tenant matters: A review of social housing regulation. Wetherby: Communities and Local Government Publications.

Cohen, M. D., March, J. G., \& Olsen, J. P. (1972). A garbage can model of organizational choice. Administrative Science Quarterly, 17(1), 1-25.

De Bruijn, J. A., Ten Heuvelhof, E. F., \& In 't Veld, R. (2002). Process management, why project management fails in complex decision making processes. Boston: Kluwer.

De Kam, G. (2004). Samenwerking bij stedelijke herstructuring [Collaboration in urban renewal]. In O. Van der Wal (Ed.), Nieuw Cement, een tussenstand van de wijkvernieuwing in Groningen [New Mortar, a mid-term review of urban renewal in Groningen]. Groningen: Platform Gras.

Van der Wal, O. (2004). Introductie, Werken aan de stad [Introduction, Developing the city]. In O. Van der Wal (Ed.), Nieuw Cement, een tussenstand van de wijkvernieuwing in Groningen [New Mortar, a midterm review of urban renewal in Groningen]. Groningen: Platform Gras.

Doherty, J. (2004). European housing policies: Bringing the state back in? European Journal of Housing Policies, 4(3), 253-260.

Edelenbos, J. (2004). Politiek and Herstructurering [Politics and urban renewal]. In O. Van der Wal (Ed.), Nieuw Cement, een tussenstand van de wijkvernieuwing in Groningen [New Mortar, a mid-term review of urban renewal in Groningen]. Groningen: Platform Gras.

Frenay, K. (2006). Verder bouwen aan vertrouwen, over samenwerking met buurtbewoners in de stad Groningen [Further developing trust, On collaboration with residents in Groningen]. Groningen: Gemeente en gezamenlijke corporaties in Groningen.

Giddens, A. (1979). Central problems in social theory. London: Macmillan.

Giddens, A. (1984). The constitution of society: Outline of the theory of structuration. London: Macmillan. 
Hirst, P. (1990). Representative democracy and its limits. Cambridge: Polity Press.

Kickert, W. J. M., Klijn, E. H., \& Koppenjan, J. F. M. (Eds.). (1997). Managing complex networks; strategies for the public sector. London: Sage.

Kingdon, J. W. (1984). Agendas, alternatives and public policy (2nd ed.). New York: Boston: Little, Brown \& Company, Harper Collins College Publisher.

Klijn, E. H., \& Koppenjan, J. F. M. (2007). Governing policy networks. In G. Morcul (Ed.), Handbook of decision making. USA Boca Raton: CRC Taylor and Francis Group.

Klijn, E. H., Koppenjan, J. F. M., \& Termeer, C. J. A. M. (1995). Managing networks in the public sector: A theoretical study of management strategies in policy networks. Public Administration, 73(3), 437-454.

Koppenjan, J. F. M., \& Klijn, E. H. (2004). Managing uncertainties in networks. London: Routledge.

Marsh, D., \& Rhodes, R. A. W. (1992). Policy networks in British government. Oxford: Clarendon.

Mullins, D., \& Rhodes, M. L. (2007). Special Issue on network theory and social housing. Housing Theory and Society, 24(1), 1-13.

Osborne, D., \& Gaebler, T. (1992). Reinventing government. USA: Addison-Wesley.

Ouwehand, A. (2004). Sociale wijkvernieuwing, tijdelijk nieuw, altijd dynamisch [Social investements in Urban renewal temporally new, always dynamic]. In O. Van der Wal (Ed.), Nieuw Cement, een tussenstand van de wijkvernieuwing in Groningen [New Mortar, a mid-term review of urban renewal in Groningen]. Groningen: Platform Gras.

Priemus, H. (2004). Housing and new urban renewal: Current policies. European Journal of housing policy, $2,229-246$.

Priemus, H., Kleinman, M., Maclennan, D., \& Turner, B. (1993). European monetary, economic and political union: Consequences for national housing policies. The Hague: Delft University Press.

Ripley, R. B., \& Franklin, G. (1987). Congress, bureaucracy and public policy. Homewood, IL: Dorsey.

Sørensen, E., \& Torfing, J. (Eds.). (2007). Theories of democratic network governance. London: PalgraveMacMillan.

Swyngedouw, E. (2005). Governance innovation and the citizens, the Janus face of governance-beyond-the state. Urban Studies, 41(11), 1991-2006.

Teisman, G. R. (1998). Complexe besluitvorming, een pluricentrisch perspectief op besluitvorming over ruimtelijke investeringen [Complex decision-making, a pluri-centric perspective on decision-making in spatial investments]. The Hague: Elsevier.

UNECE. (2006). Guidelines for social housing. New York and Geneva: UNECE.

Van Bortel, G. A., \& Elsinga, M. A. (2007). A network perspective on the organization of social housing in the Netherlands: The case of urban renewal in The Hague. Housing Theory and Society, 24(1), 32-48.

Van Bortel, G. A. \& Van der Helm, K. (2006) Discussion paper for Conference New Local Urban Renewal Covenan. Unpublished.

Van de Wijdeven, T. M. F., \& De Graaf, L. (2008). Met vertrouwen van start in de Groningse wijkvernieuwing. Tilburg: Universiteit van Tilburg.

Van Hulst, M. J., Van de Wijdeven, T. M. F., Karsten, N., \& Hendriks, F. (2008). Aandacht voor bewonersparticipatie [Focus on citizens participation]. Tilburg: Universiteit van Tilburg.

VROM. (2006). Stad en stijging, Sociale stijging als leidraad voor stedelijke vernieuwing [City and social mobility, social mobility as leading principle for urban renewal]. The Hague: VROM-council.

VROM. (2007). Actieplan Krachtwijken: Van aandachtswijk naar krachtwijk [Action plan Empowered neighbourhoods: From a priority neighbourhood towards an empowered neighbourhood]. The Hague: Ministerie van VROM.

Weick, K. E. (1995). Sensemaking in organizations. Thousand Oaks: SAGE Publications.

Whitehead, C., \& Scanlon, K. (2007). Social housing in Europe. London: LSE.

WRR. (2005). Vertrouwen in de buurt [Confidence in the Neighbourhood]. The Hague: WRR. 